\title{
Disseminated atypical molluscum contagiosum as a presenting symptom of HIV infection
}

\author{
Marta Filo-Rogulska' ${ }^{1}$, Malgorzata Pindycka-Piaszczyńska ${ }^{1}$, Krzysztof Januszewski², Jerzy Jarzą ${ }^{1}$ \\ 1Department of Internal Medicine, Dermatology and Allergology, Medical University of Silesia, Zabrze, Poland \\ Head: Jerzy Jarząb MD, PhD \\ 2Department of Pathology, Teaching Hospital No. 7, Medical University of Silesia, Katowice, Poland \\ Head: Krzysztof Januszewski MD, PhD
}

\begin{abstract}
Atypical forms of molluscum contagiosum may be challenging to diagnose and are found in immunocompromised patients where they indicate severe impairment of cellular immunity. We report a case of disseminated atypical molluscum contagiosum which was the first sign of HIV infection and AIDS disease in a 38-year-old male patient. The lesions - painless, flesh-colored and violaceous papules and nodules - spread systematically for previous 3 years. They were located on the face, forearms, in the groins and in the genital region. Serologic tests for HIV-1 and hepatitis C virus were positive. CD4+ T-cells count was $80 / \mathrm{mm}^{3}$. The skin biopsy showed intracytoplasmic molluscum bodies. Atypical, recalcitrant, disseminated or facial molluscum contagiosum requires immediate HIV testing. In our patient, both the opportunity for early diagnosis and the institution of effective therapy were missed.
\end{abstract}

Key words: molluscum contagiosum, HIV, AIDS-related opportunistic infections, skin biopsy.

\section{Introduction}

Molluscum contagiosum is most frequently a self-limiting benign viral skin disease. In the case of typical lesions the diagnosis is straightforward. Atypical presentations occur commonly in immunocompromised patients and require differentiation from basal cell carcinoma, keratoacanthoma, Darrier's disease and cutaneous cryptococcosis. Individual lesions are often larger than typical (3-5 $\mathrm{mm}$ ) and may reach as many as $15 \mathrm{~mm}$. The lesions may be numerous and they may coalesce into larger agglomerations and nodules [1]. The disease involves primarily the face and the trunk, whereas in immunocompetent adults it is usually limited to the genital area [2]. Atypical molluscum contagiosum requires a histopathological confirmation.

\section{Case report}

A 38-year-old male construction worker was referred to our department with multiple, painless, flesh-colored and violaceous papules and nodules. They were located primarily on the face, forearms, in the groins and in the genital region (Figure $1 \mathrm{~A}$ ). Upon compression some of the papules released white caseous contents. The first lesions had been observed in the right cubital fossa three years earlier. They had been treated with cryotheraphy and topical salicylic acid with a good effect but they recurred and spread systematically over time. The patient did not report any incidence of similar lesions in his family members. He denied casual sex and illicit drug use. He had been smoking 10 cigarettes a day since he was 18 years old and had been drinking approximately 3 alcohol drinks a week.

Beside skin lesions, the physical examination revealed generalized lymphadenopathy, hepatomegaly and oropharyngeal thrush. Neck, axillary and inguinal lymph nodes were swollen, non-tender and moveable. Laboratory panel was obtained. Throat swab and papules content were cultured for both bacteria and fungi.

Complete blood count showed slight leukopenia $4.4 \mathrm{~K} / \mu \mathrm{l}$, normal erythrocytes count $4.5 \mathrm{M} / \mu \mathrm{l}$, platelets count $308 \mathrm{~K} / \mu \mathrm{l}$ and hemoglobin concentration $14 \mathrm{~g} / \mathrm{dl}$. Manual blood smear showed $27 \%$ of lymphocytes and $64 \%$ of neutrophils. Liver function tests except for bilirubin were all

Address for correspondence: Marta Filo-Rogulska MD, Department of Internal Medicine, Dermatology and Allergology, Medical University of Silesia, 10 M. Skłodowskiej-Curie Str., Zabrze, Poland, phone: +48 602736 723, fax: +48 322716 471, e-mail: filo.rogulska@gmail.com Received: 25.03.2012, accepted: 23.09.2012. 

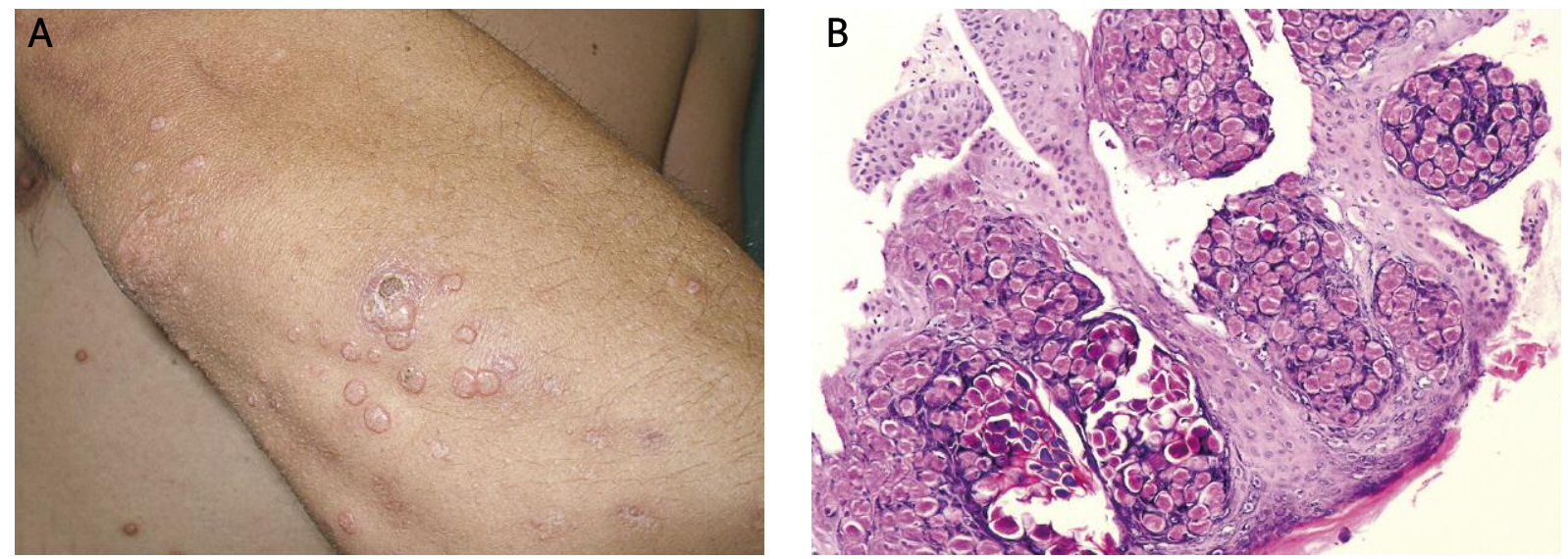

Figure 1. Papules and nodules on the forearm (A). Biopsy specimen from the forearm. Molluscum inclusion bodies (hematoxylin-eosin stain, 40× magnification) (B)

abnormal. Alanine and asparagine aminotransferase activities were $57 \mathrm{IU} / \mathrm{ml}$ and $59 \mathrm{IU} / \mathrm{ml}$, respectively. $\gamma$-Glutamyl transferase activity was $-276 \mathrm{IU} / \mathrm{ml}$. Total bilirubin concentration was $0.5 \mathrm{mg} / \mathrm{dl}$. Creatinine and blood urea nitrogen were within the normal range. Total serum protein concentration was $8.8 \mathrm{~g} / \mathrm{dl}$. Protein electrophoresis showed relative hypoalbuminemia (37\%) and hypergammaglobulinemia (38\%). Serologic tests for HIV-1 and hepatitis $C$ virus were both positive. Syphilis and hepatitis $B$ virus tests returned negative. CD4+ T-cells count was obtained and was significantly low -80 cells $/ \mathrm{mm}^{3}$. Chest $\mathrm{X}$-ray revealed postinflammatory lesions in the upper lobe of the left lung of possibly tuberculous origin. Abdominal ultrasound showed enlarged, hyperechogenic liver and pancreas with sonographic characteristics of chronic inflammation.

Biopsy was taken from a nodule on the forearm. Large, eosinophilic, hyaline intracytoplasmic inclusions suggestive of molluscum (Henderson-Patterson) bodies were identified in reticular dermis (Figure $1 \mathrm{~B}$ ). Co-infection of lesions with Cryptococcus neoformans was excluded by negative culture. Throat culture confirmed abundant growth of Candida albicans.

The patient was referred to a dedicated HIV/AIDS management center for further evaluation and treatment.

\section{Discussion}

Cutaneous lesions are frequently the first presenting signs of an HIV-infection. Their occurrence and severity are closely correlated with disease progression to a point when skin examination enables rapid assessment of the patient's immunological condition (Table 1). Such surrogate method is frequently used in resource-poor settings and constitutes an important part of the WHO clinical staging system [3, 4]. Apart from decreasing CD4+ T-cells count, two other mechanisms are postulated in pathogenesis of HIV-related skin diseases: decreased count of skin anti-

Table 1. Association between clinical and immunological status of the HIV-infection and skin manifestations [3, 8, 14-17]

\begin{tabular}{lll}
\hline Clinical status & $\begin{array}{c}\text { CD4+ T-cells count } \\
{\left[\text { cells } / \mathrm{mm}^{3}\right]}\end{array}$ & Mucocutaneous manifestations \\
\hline Acute HIV infection & $>200$ & $\begin{array}{l}\text { Seborrheic dermatitis, xerosis, condylomata, herpes zoster, } \\
\text { recurrent oral ulcerations, angular cheilitis, fungal nail infections, } \\
\text { prurigo nodularis }\end{array}$ \\
\hline $\begin{array}{l}\text { Early chronic HIV-infection } \\
\text { (WHO Stage 1-2) }\end{array}$ & $\begin{array}{l}\text { Kaposi's sarcoma, new onset of psoriasis or atopic dermatitis, } \\
\text { eosinophilic folliculitis, photodermatitis, adverse drug reactions, } \\
\text { oral hairy leucoplakia, persistent oral candidiasis, acute necrotizing } \\
\text { gingivitis, chronic herpes simplex infection (> 1 month duration) }\end{array}$ \\
\hline $\begin{array}{ll}\text { Advanced chronic HIV-infection } \\
\text { WHO Stage 3-4) }\end{array}$ & $\begin{array}{l}\text { Kaposi's sarcoma with internal organs involved, severe opportunistic } \\
\text { infections with fungi, viruses and bacteria (including molluscum } \\
\text { contagiosum), severe drug reactions - Stevens-Johnson syndrome }\end{array}$ \\
\hline Co-infection with HCV & $<100$ & $\begin{array}{l}\text { Lichen planus, xerosis, leukocytoclastic vasculitis, generalized pruritus } \\
\text { resistant to antihistamines }\end{array}$ \\
\hline
\end{tabular}


gen presenting cells and observed shift into Th2 cytokine profile responsible for impaired cellular immunity and ineffective inflammatory response [5-7]. Coupled with a progressive character of an HIV-infection, these mechanisms may be responsible for unusual clinical presentations of classical dermatological entities. Thus, atypical, recalcitrant, disseminated or facial molluscum contagiosum requires immediate HIV testing, especially in adult patients. In our patient both the opportunity for early diagnosis and the institution of effective therapy were missed.

Clinically apparent molluscum contagiosum infection develops in between $5 \%$ and $18 \%$ of HIV-positive patients $[8,9]$. The extent of molluscum infection correlates inversely with CD4+ T-cells count [1]. Differential diagnosis in HIV-positive patients must include cutaneous cryptococcosis which frequently resembles molluscum contagiosum. Interestingly, these two pathogens have been reported to co-exist in the same lesion [10].

Optimal treatment of molluscum contagiosum in HIV-positive patients is restoration of immunological competence by anti-retroviral therapy. However, cases resistant to standard treatment have been reported [11]. Recently, a report by Sisneros has shown successful treatment of resistant severe molluscum contagiosum with an anticancer drug - paclitaxel [12]. A postulated mechanism of action is interference with cellular microtubule system used by poxviruses during their reproduction cycle [13].

\section{References}

1. Schwartz JJ, Myskowski PL. Molluscum contagiosum in patients with human immunodeficiency virus infection. A review of twenty-seven patients. J Am Acad Dermatol 1992; 27: 583-8.

2. Katzman M, Carey JT, Elmets CA, et al. Molluscum contagiosum and the acquired immunodeficiency syndrome: clinical and immunological details of two cases. Br I Dermatol 1987; 116: 131-8.

3. Nnoruka EN, Chukwuka JC, Anisuiba B. Correlation of mucocutaneous manifestations of HIV/AIDS infection with CD4 counts and disease progression. Int I Dermatol 2007; 46: 14-8.

4. World Health Organization. WHO Case Definitions of HIV for Surveillance and Revised Clinical Staging and Immunological Classification of HIV-Related Disease In Adults and Children 2007. Available at: www.who.int/hiv/pub/guidelines/HIVstaging150307.pdf. Accessed December 8, 2011.

5. Vera-Sempere FJ, Rubio L, Massmanian A. Counts and areas of S-100-positive epidermal dendritic cells in atypical molluscum contagiosum affecting HIV+ patients. Histol Histopathol 2001; 16: 45-51.

6. Amerio P, Verdolini R, Proietto G, et al. Role of Th2 cytokines, RANTES and eotaxin in AIDS-associated eosinophilic folliculitis. Acta Derm Venereol 2001; 81: 92-5.

7. Jabłonowska E, Kołacinska A, Kuydowicz J, et al. Interleukin6 and the IL- $6(-174)$ C/G polymorphism in breast pathologies and in HIV-infected patients. Arch Med Sci 2010; 6: 860-5.
8. Coopman SA, Johnson RA, Platt R, Stern RS. Cutaneous disease and drug reactions in HIV infection. N Engl J Med 1993; 328: 1670-4.

9. Coldiron BM, Bergstresser PR. Prevalence and clinical spectrum of skin disease in patients infected with human immunodeficiency virus. Arch Dermatol 1989; 125: 357-61.

10. Annam V, Inamadar AC, Palit A, Yelikar BR. Co-infection of molluscum contagiosum virus and cryptococcosis in the same skin lesion in a HIV-infected patient. J Cutan Pathol 2008; 35: 29-31.

11. Baxter KF, Highet AS. Topical cidofovir and cryotherapy-combination treatment for recalcitrant molluscum contagiosum in a patient with HIV infection. J Eur Acad Dermatol Venereol 2004; 18: 230-1.

12. Sisneros SC. Recalcitrant giant molluscum contagiosum in a patient with advanced HIV disease - eradication of disease with paclitaxel. Top HIV Med 2010; 18: 169-72.

13. Ploubidou A, Moreau V, Ashman K, et al. Vaccinia virus infection disrupts microtubule organization and centrosome function. EMBO I 2000; 19: 3932-44

14. Schechner AJ, Pinson AG. Acute human immunodeficiency virus infection presenting with erythema multiforme. Am J Emerg Med 2004; 22: 330-1.

15. Cedeno-Laurent F, Gómez-Flores M, Mendez N, et al. New insights into HIV-1-primary skin disorders. J Int AIDS Soc 2011; 14: 5.

16. Maurer TA. Dermatologic manifestations of HIV infection. Top HIV Med 2005; 13: 149-54.

17. Markowska A, Lubin J, Jaszczyńska-Nowinka K, et al. Influence of viral, bacterial and parasitic infections on the development of neoplasia. Wspolczesna Onkol 2011; 15: 7-14. 